\title{
THE BASIS OF BOBANQUET'S LOGIC.
}

I Ax 80 much interested in Mr. Leonard Russell's point of view (Mird, Ootober, 1920), that I will venture, if I may, this once more, to try to meet it as far as I can.

On one matter, indeed, I do not see my way to any agreement. It seems to run right through the discussion. It is the question whether I am bound, on my premisses, to hold that the subject of a hypothetioal judgment must exist in fact (l.c., p. 476). The resson is, as I understand, that I hold the ultimate subject of the judgment to be reality.

In my view it is this doctrine which gives me absolute freedom in my account of the immediste subject of judgment. I take it to be the essence of thought to qualify reality as a whole; and the instrument of its operation I take to be always a discrimination, including in this term selection and combination, within the whole content which reality offers as experience. Any discriminated content that will prescribe apecial line of connexion within the whole will serve as the immediste subject of a judgment. The name of a real thing suggests a resl subject tsken as it is given. But the sntecedent of a hypothetical judgment, usually an ides introduced by an "if," suggests at once something divergent from given reality. The "if" introduces an idesl subject, of which the consequent predicates something not true of it as it stends, but true in the light thrown on it by its connexion with what is relovant in the whole. The resson why I say that this is fundamental is that I cannot comprehend the notion of a thought which does not operate towards qualifying the whole reality. Thought, I should have said, strictly spesking, is the whole or the reality operating through minds to qualify itself by establishing definite coherences prescribed by discriminated conditions. Thus I can see nothing in the point that knowledge cannot be based on the whole reality, beasuse it is based on discriminated systomatic connezions. It is based, I believe, on a systematio connexion at every point of affirmation, but never on any connexion apart from the oriterion of the whole content, the appeal to which is its nisus and its nature. The whole specified in its parts in the light of the wholo - that is what I understand by knowledge as a construction crested by thought.

Sabject to this difference of opinion, I can agree that we get knowledge by " constructing a world," but this only in a definitely. limited sense and degree, which I will recur to, "other than the 
resl world" (p. 474). The main work of construction is, I believe, ordering and adjusting the world of experience in 'obedience' to the principle of totality which is the law of coherence. Surely Mr. Bussell would not say with Gentile that thinking simply creates the world? As I understand, we make it in discovering it, and discover it in making it.

But this factor of agreement, which goes very deep with reference to the active character of thought, is yet modified by a further difference between us, though again, I hope, re-modified towards Mr Russell's position by a further explanation. I am writing as, shortly as 1 possibly can, and beg for a favourable hesring.

The further difference is this. I admit the work of construction, but cannot agree that it comes under the head of supposition or position. Therefore I must deny that " posited systems are at the basis of our whole explicated knowledge of reality" (p. 475).

Supposition, as I see the matter, is not construction, and connot construct a world. Construction is the complete work of thought, of judgment. Supposition is ideal experiment, and has the limitation of all experiment. The experiment is one thing; the judgment upon it is another. The whole purpose of the experiment is to see how the real world reacts-how the special track we have selected opens up and continues-in consequence of what the experiment does. Why does "reality" make a difference and furnish the test? Because reality is the whole; it does not matter which word you use; and the whole is the criterion of thought. I am not sure whether Mr. Rusgell mesns that he formulated his view, that science is necessary to contradict science (p. 474 top), in opposition to mine or because of it; but $I$ say it in so many words (Logic," i., p. 297 n.). Only, supposition does not tell you whether science is for you or against you. It is solely when you have judged, that you have committed yourself to a survey of the whole, which says that there is no superior generalisation against you. I agree that content is what you have to consider; but it seems to me to be only in the judgment, which affirms of reslity, that you have the whole content brought to bear. Strictly, you cannot have a posited system. For you cannot posit the consequences, the unification, of combinations. You can only judge them.

But we seem to have such a thing. We seem sble to suppose a world, in erecting which we draw consequences and so unify combinations. Here we are misled, I believe, by the feature, apt to pass unnoticed, of conclusion premisses (cf. Im plication, pp. 65-66). The moment you glance at posited data, inference begins to grow. Consequences begin to $\mathrm{dr}_{\mathrm{w}} \mathrm{w}$ themselves long before the main conclusion is drawn. "All men are mortal" is put forward as a premiss. But it is chock-full of conclusions. And so is the structure of any coherent system which, we say, in current language, that we "posit" or "suppose". The moment we look at the factors of our supposition taken together, judgment 
and inference, which go beyond it, begin. The criterion of the whole, and the appeal to it, is inherent in our thought, and cannot be barred out.

This was my further difference. I agreed that thought was productive; but I do not agree that its operation as such can be identified with supposition.

But now I have a re-modification to offer which will take me, I hope, some little way at lesst back towards agreement.

Mr. Russell had in mind (October, 1918, p. 447) the nonEuclidean geometries. Now I have no right to say a word as of myself on this subject. But I find a discussion by Prof. Alexander (in Space, Tims and Deity, i., pp. 157, $160 \mathrm{ff}$.) whioh seems relevant and suggestive. It is instructive in itself that Prof. Alexander discusses them under the seation-hesding "A Product of Art". He compares the construction of them "with the arbitrary act of imagination by which we construct a chimera". They are "the investigation of certain notions for their own sake when freed from their sttachments". They are products of free thought "giving rise to fresh combinations". Yet they retein a kinship with nature such that they give us valuable knowledge, which can perhaps also be said, but certainly in a sense much more remote, of works of att (Alexander, pp. 161-162). Discrimination within the whole has here passed into divergent supposition. Abstraction and combination have led the way to a posited world-other than the real world.

This, I take it, is the sort of cese which Mr Russell is determined to have recognised. Here we certainly get knowledge, and we seem to get it by constructive thinking about an assumption or supposition. I fully admit the importance and significance of the topio. I only venture to suggest two remarks : (1) Pare thought, in drawing consequences, seems to me to transcend supposition by ssserting, not positing, its own laws; (2) it also seems to me to transcend supposition just because it pursues the suggestion freely and constructively, i.e., it takes, out of a complete survey of reality, any and every consequent which the supposition indicates to be relevant. Thought would contradict its own nature, and would fail to be crestive, if it confined itself to dwelling on the content of an assumption. Rather, like art, it works out the possibilities to which a notion, applied to the whole of content without restriction, gives it the clue.

Then, to come to terms with Mr. Russell's ultimatum (p. 477); "The judgment, I should say, is always and inevitably based on such a partial system, though referring to the whole of reality" : $I$ should asy that $I$ believe $I$ understand what it mesns, and that I recognise in it, as, I have explained, high practical truth in the cast of certain freely constructed systems; but strictly and ultimately I cannot but hold it to be a contradiction in terms. A judgment which refers to the whole of reslity must, in principle, be modelled by coherence with it. In a given case the demands of the whole 
194 BERNAKII JIOSANQUET: BA8IS OF BOSANQUET'S LOGIC.

may make no apparent difference to that one out of innumerable partial systems whioh is more immediately in question. But this cannot be because the whole of content has not to be consalted, but only becsuse, allowing for undeveloped interdependence of eystems, its answer is on the whole taken to be favourable.

Bernakd Bogamquet. 